\title{
THE NEW CULT OF PAX AUGUSTA 13 BC - AD 14
}

Summary: As Augustus returned to Rome in $13 \mathrm{BC}$, the Senate passed a constitutio to build in his honor a lasting altar of peace, the Ara Pacis Augustae, to signal with a major ceremony the new peace all over the Roman world, Gibbon's Pax Romana. As we know from Ovid Fast. 1. 709-714, 3. 881-882, the Ara Pacis was the site of two annual sacrifices (on $30 \mathrm{Jan}$. and $30 \mathrm{March}$ ) to Pax, an innovation of the Augus$\tan$ Age, for formerly Pax had been a minor goddess without a temple. The Augustan regime elevated a new form of Pax as a religious cult and made it acceptable to the Roman people, who had regarded Pax as the phenomenon of a foreign power too beaten down to resist Roman arms any longer and had no use for pacifism (in the modern sense), which would be seen only as cowardly in their dangerous world.

Augustus had started this process, perhaps not intentionally, back when he closed the Gates of Janus in 29. By bringing together Greco-Roman elements of Pax with Jupiter and Janus, he was able to forge a new religious cult to Pax Augusta that could appeal to the average Roman by its promise of prosperity and the absence of civil war. Foreign war was perfectly acceptable and not incompatible with this cult, but the emphasis was on domestic harmony and old traditional religious practices, even if the average listener could not understand some of these obligatory, archaic chants. For this reason, the third closing of the Gates of Janus very likely accompanied one of the Ara Pacis ceremonies.

Augustus also built on precedents from his divine father Julius, who had founded the towns Forum Iulii Pacatum (Fréjus, France) and Pax Iulia (Beja, Portugal) and issued Pax imagery on coinage to gain the moral high ground during the civil war. Augustus went one step further with larger sets of Pax coin issues to tell the people that he, not Antony, was trying to maintain peace when Cleopatra wanted war, and then a sequel after Actium that demonstrated his ability to prevail and restore order. The image of Pax Augusta evolved as it developed, but the epitome is the goddess we see on the East side of the Ara Pacis, surrounded by fertility and prosperity, in a state of security. Rome too would enjoy the same benefits.

Key words: Augustus, Pax Romana, Janus, Gates of Janus, Roman coinage

At the much-anticipated dawn of the New Golden Age, Augustus' regime revealed to the public a new version of Pax, namely, Pax Augusta, a cult figure with two annual holidays, to illustrate to the people the successes of the New World Order, and the idyllic future Rome was about to enter now that the era of civil war has passed. The introduction of $\mathrm{Pax}$ as an important cult figure required a major effort, for Romans 
viewed peace with suspicion as a nearly distasteful concept, except when inflicted upon the defeated enemies of Rome, who had been warred down beyond their ability to resist (Vergil, Aen. 6. 853: parcere subiectis et debellare superbos), ${ }^{1}$ and certainly Romans had no use for pacifism (in the modern sense), which was generally considered cowardice in their dangerous world. Therefore the Augustan regime exerted the utmost pomp and pageantry to present to the people the case that Pax was welcome, beneficial, and a just reward for a people who had toiled and suffered under nearly a century of internal conflict and civil war.

The history of the cult of Pax in the Greek world, from which Augustus borrowed certain themes and imagery, appears in the pages of Homer and Hesiod, but did not achieve formal status until after the King's Peace of 386. Homer compares the polis at war and at peace on the shield of the Achilles, favoring peace, while He-

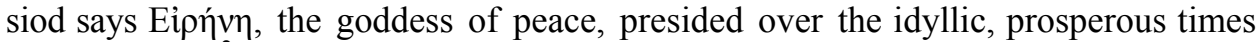
between wars. ${ }^{2}$ It is widely known how the Greeks would temporarily suspend war for the Olympic Games. The complex relationship between war and peace can be seen from the fact that many of the sports are actually peaceful exercises of military maneuvers (the javelin throw and the race in heavy armor, for example). Aristophanes Peace 221-226, originally staged just a few days before the Peace of Nicias in 421, describes the goddess imprisoned in a cave by War. ${ }^{3}$ Two of her earliest known appearances in art were a Locrian stater $^{4}$ ca. 350 (Fig. 1) that depicts a seated Eipńv the caduceus in her hand, and the statue Peace and Wealth, ca. 375 (Paus. 1. 8. 3), by Cephisodotus (Fig. 2), the likely father of Praxiteles. Cephisodotus's statue, commissioned after Chabrias's naval victory over Sparta at Naxos, aptly shows the relationship between peace and wealth, mother and son. Peace looks adoringly at her son Wealth, whom she cradles in her left arm. Wealth looks back at her and reaches for her chin with his right hand, in a pose Praxiteles must have copied in Hermes Holding the Infant Dionysus (Fig. 3). Her left hand probably held a scepter but not the caduceus that later became standard. After the Battle of Leuctra in 371, the Athenians initiated an annual festival to Peace at which a performance of Aristophanes' play would be fitting. In the Hellenistic Era, Theocritus' Idyll 16 praised Hiero II of Syracuse for pledging to restore order to Sicily and foretold a glorious peace to come,

${ }^{1}$ Momigliano, A.: The Peace of the Ara Pacis. Journal of the Warburg and Courtauld Institutes 5 (1942) 228-231.

${ }^{2}$ Hes. Theog. 901 ff., Works 228.

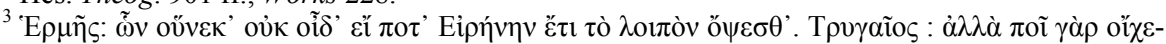

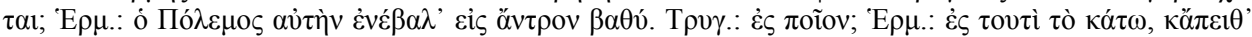

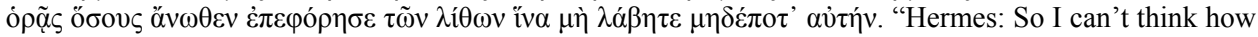
you'll ever see Peace again. Trygaeus: Why? Where have they taken her? Herm.: War had her dropped in there. It's a deep cave down there! Tryg: It's a what? Herm: A deep, deep cave. And he stacked up that huge pile of boulders over it so that you'll never be able to get her." (transl. by G. Theodoridis [2002], from http://www.poetryintranslation.com/PITBR/Greek/Peace.htm). The situation is reversed in Verg. Aen. 1. 294-296.

${ }^{4}$ All coin images come courtesy of David Freeman from Freeman and Sear (http://www.wildwinds. com/coins/ric/augustus/i.html), except Figures 17, 18A, 18B, and 18F, which come from my own collection. 

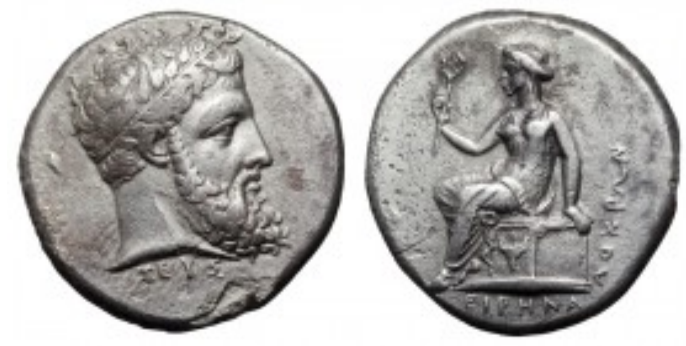

Fig. 1. Locrian stater

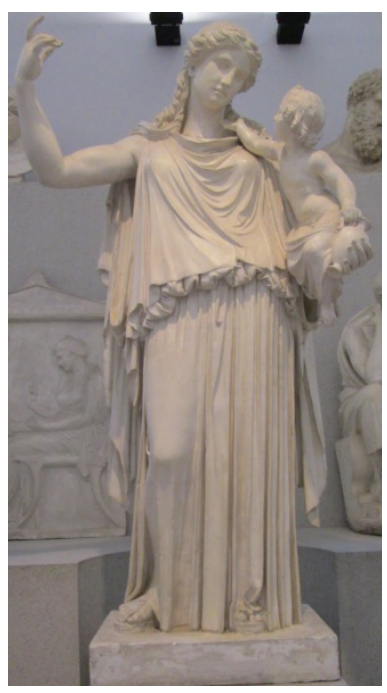

Fig. 2. Cephisodotus, Peace and Wealth. Copy in Museo Civico Archeologico Bologna (Photo Gaius Stern).

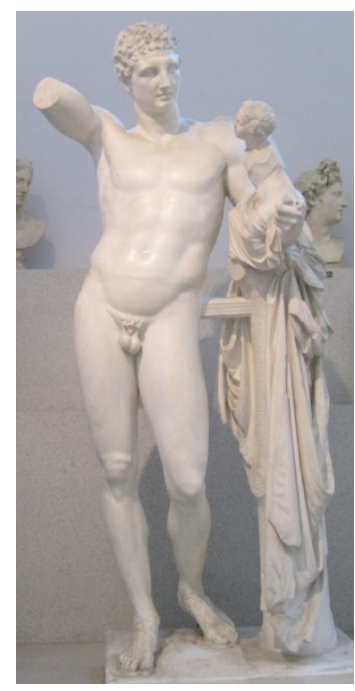

Fig. 3. Praxiteles, Hermes Holding the Infant Dionysus. Copy in Museo Civico Archeologico Bologna (Photo Gaius Stern).

a theme Vergil also circulated. And yet despite a number of opportunities that would have been exploited under Roman leaders, the successors of Alexander the Great rarely if ever minted coins with the image of peace. ${ }^{5}$ Apparently, starting in $280 \mathrm{BC}$ and into the Roman Empire, the Asian polis Nysa, birthplace of Dionysus, began to

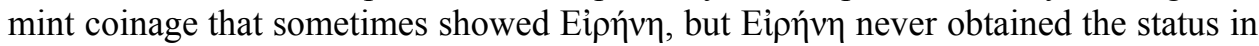
the Greek world prior to Roman intervention that Augustus brought to Pax.

In Aen. 7. 601 ff., Vergil places the Gates of Janus, later the bellwether of Roman war and peace, in ancient Latium, serving a common purpose for all the Alban cities. When Latinus refuses to declare war on the Trojans, Juno herself throws them

${ }^{5}$ The opportunities included the succession resolutions and settlements in 321 and 317 , the lull in fighting after the Battles of Ipsus in 301 (maybe a little less so after Corrupedion in 281), and parts of the reigns of Ptolemy II and Antigonus II Gonatas. 
open (7. 620-622). We should not trust Roman testimony for an ancient Latin origin of the cult of peace, although it is rich and ample. Early Roman mythology told two conflicting stories about an idyllic, primordial past in which mankind knew neither war nor strife. Vergil and Ovid say that Saturn ruled a Golden Age of peace before Jupiter, in which mankind knew neither fear nor punishment, nor had a need for either one. ${ }^{6}$ Peace, justice, and fertility prevailed, and mankind was free of want. But when Jupiter overthrew his father Saturn, the Silver Age replaced the Golden Age and introduced war and injustice. Macrobius (Sat. 1. 7. $21 \mathrm{ff}$.) and others say Saturn fled by ship to Italy, where Janus welcomed him. Saturn introduced grafting and seeding, for which Janus gave him part of the kingdom to rule, and together they ruled a Golden Age of peace over the rustic Hesperians. ${ }^{7}$ Janus invented coinage on which he honored Saturn by stamping an image of his ship. Macrobius says this is why children flip coins in the game "heads or ships". ${ }^{8}$ After a lengthy, joint reign, Saturn suddenly disappeared without explanation. To honor his lost friend, Janus renamed the kingdom Saturnia, built him an altar, invented the Saturnalia, and made the sickle Saturn's symbol. Macrobius 1. 7. 26 says "Saturn's reign is said to have been a time of great happiness, both on account of the universal plenty that then prevailed and because as yet there was no division into bond and free - as one may gather from the complete license enjoyed by slaves at the Saturnalia."

According to Livy, Numa Pompilius the second king of Rome, in deliberate contrast to Romulus son of Mars, taught the arts of peace and awed the people with superstition to keep them obedient. He had them build a temple to Janus, which would indicate whether Rome was at war or peace, and throughout his legendary reign of 43 years, greatly outdid Woodrow Wilson in keeping Rome out of war. ${ }^{10}$ Neighboring kings so respected his pietas that they refrained from attacking Rome. However, the third king of Rome, Tullus Hostilius, devised a war against Alba Longa and reopened the Gates of Janus, which remained opened for the next 450 years.

A few years after the First Punic War ended, the Romans finally closed the Gates of Janus again in the first known, historical Roman celebration of the cult of peace in $235 \mathrm{BC}$. The complete absence of foreign war did not last for long. Gallic invasions in the 220 s brought a return to war, which lasted for another 200 years, until Augustus. Nevertheless, the theme of peace colors Livy's readers against Carthage in 218 when Q. Fabius Buteo brought to Carthage a hasta as a symbol of war and a caduceus as a symbol of peace from which the Carthaginians were to choose their

${ }^{6}$ Verg. Georg. 1. 125-128, Ecl. 4. 7-8; Ov. Fasti 1. 235 ff., Met. 1. 89 ff. See also Macr. Sat. 1. 9. 1.

${ }^{7}$ Macr. Sat. 1. 9. 1.

${ }^{8}$ Macr. Sat. 1. 7. 22.

${ }^{9}$ Macrobius also records two other versions for the creation of the Saturnalia: followers of Hercules created it or exiled Pelasgians came to Italy and drove out the Sicels, after which they raised a shrine to Dis and founded the holiday.

${ }^{10}$ In 1916, Pres. Wilson campaigned on the slogan "he kept us out of war" and was narrowly reelected. In April 1917 he asked Congress to declare war against Germany, due to the resumption of unconditional submarine warfare, bringing the US into WW I. 
pleasure. ${ }^{11}$ The image of the caduceus as synecdoche for Pax appears on coinage in the first century BC and intermittently in the hand of the goddess Pax into the first and second century AD. The caduceus carried over from Hermes/Mercury to Pax because heralds carried it as they traveled between hostile parties, as on the Louvre Briseis Vase (Fig. 4). Similarly the cornucopia, which originally stood for Demeter/Ceres, transferred over to Pax, because it shows agricultural fertility and prosperity, which Hesiod and others associated with peace. Augustus and others would sometimes employ these Greek visual cues when they invoked peace.

Romans traditionally sacrificed a pig to cement a peace treaty, ${ }^{12}$ so this image also came to be associated with Peace, as on a denarius from $137 \mathrm{BC}$. It recalls a treaty possibly between Rome and Alexander II of Epirus in 332 at the time of the Samnite Wars. ${ }^{13}$ The mint master could claim descent from Veturius the consul(s) in 334 and 321, who had fought against the Samnites. ${ }^{14}$ On the reverse two soldiers face one another while a kneeling youth holds a pig for sacrifice (Fig. 5). Another image of a pig sacrifice appears on the Ara Pacis. ${ }^{15}$ Although some other Republican coins may allude to Peace with symbols, none include her personification before $44 \mathrm{BC}$, save perhaps a denarius of L. Caecilius Metellus Daidemetus released in 126. A goddess thought to be Pax (but it could be Diana) drives a biga. The elephant, if not the entire image, refers to an ancestor's victory over the Carthaginians, in which elephants were captured (Fig. 6).

Fifty years later Norbanus Flaccus issued a denarius ca. $82 \mathrm{BC}$, whose reverse illustrates wheat, the fasces, and the caduceus to indicate agricultural fertility, prosperity, law and order, and peace under the Populares (Fig. 7). Although Pax is not mentioned by name, she is included in the general message of prosperity under the Populares. Soon after, (82/81), the tresviri monetalis (C Annius Tf Tn Luscus and L Fabius Lf Hispaniensis) minted a coin of the goddess Anna Perenna, easily mistaken for Pax, which circulates the same metaphoric references to her: prosperity, law and order, and peace, by means of the winged caduceus behind, her head, the scales under her chin, and the control symbol (e.g. syrix, tripod, sica or curved dagger) under her neck (Fig. 8).

In 49 the Pompeian mint master Sicinius released a denarius with a caduceus, victory palm, and laurel wreath to evoke much the same statement of domestic unity as Norbanus Flaccus (Fig. 9). Possibly in reply, Dec. Brutus Albinus, minted a denarius

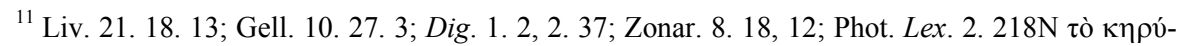

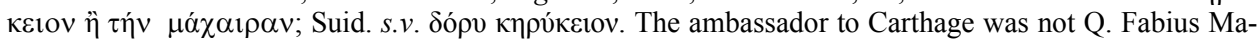
ximus Cunctator, but his kinsman, Fabius Buteo (cos. 245, dict. 216). The story of the embassy is notably absent from Plutarch's biography of Fabius Cunctator. See also BROUGHTON, TH. R. S.: The Magistrates of the Roman Republic. New York 1951. See under the year 218 BC.

${ }^{12}$ Livy 1. 24; Varro RR 2. 4. 9; Suet. Claud. 25. 5.

${ }^{13}$ Liv. 8. 17. 10. Certainly, the coin does not recall Rome's dishonorable surrender at Caudine Forks in 321 .

${ }^{14}$ Possibly the two Veturii are same person, but more likely a father and son.

${ }^{15}$ See also two coins that display priests sacrificing a pig, minted in 16 BC by Antistius Vetus, RIC Aug. 363/4 and in 13 BC by Antistius Reginus, RIC Aug. 411. 


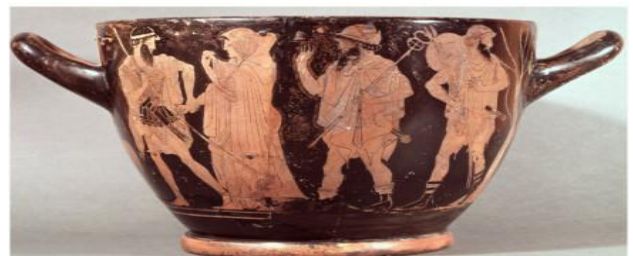

Fig. 4. Greek red figure Briseis Vase, on which heralds carry caducei. Louvre G 146, Beazley 204682.
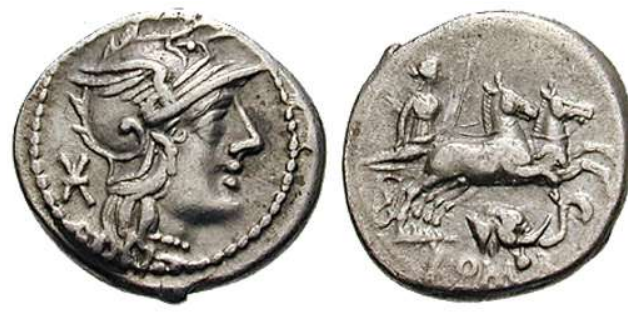

Fig. 6. Metellus denarius, 126 BC. Pax in biga, elephants head with bell around neck below
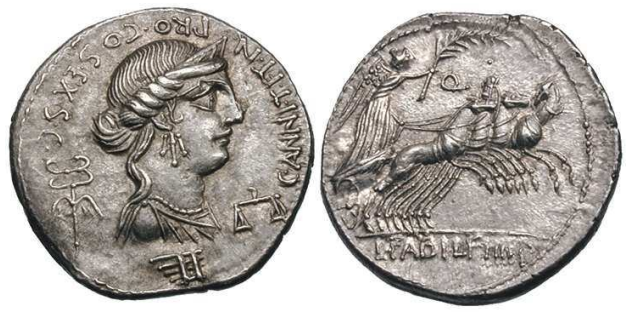

Fig. 8. Annius Luscus Fabius Hispaniensis, denarius, 81. Obv.: C ANNI T F T N PRO COS, Anna Perenna, rev.: Victory driving a biga, FABI L F HISP

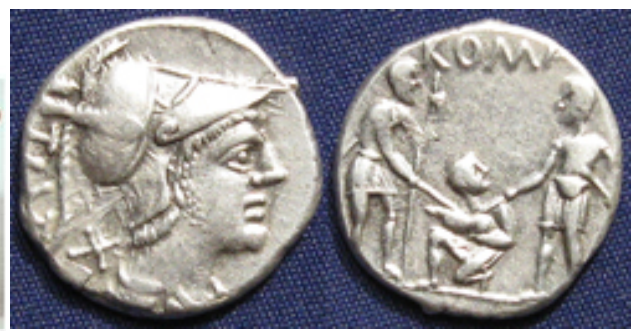

Fig. 5. Ti. Veturius, denarius, 137 BC. Mars, pig sacrifice $=$ peace treaty

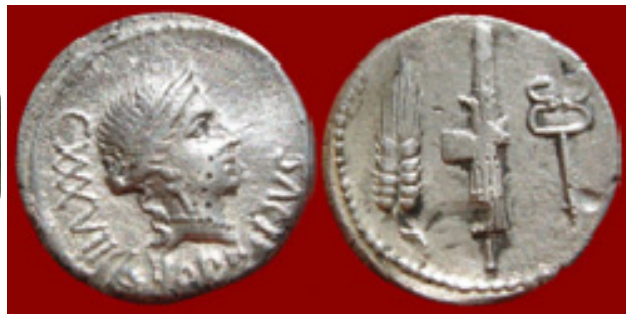

Fig. 7. Norbanus Flaccus, denarius, ca. 82. Obv.: CXXXVII C NORBANUS, ?Ceres, rev.: wheat, fasces, and caduceus
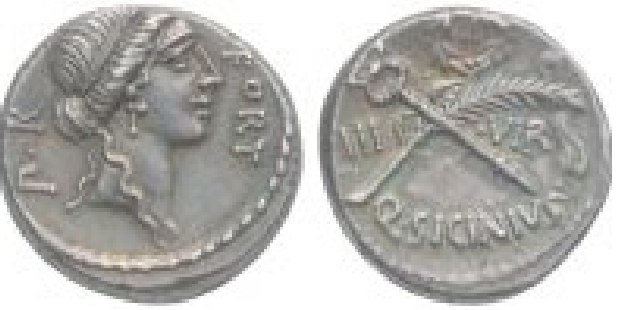

Fig. 9. Q. Sicinius, denarius, 49 BC. Claiming moral high ground in the Civil War

to assert the Caesarians as the true party of pietas, peace, and prosperity, rather than proclaim the pacification of Gallia, for which Pietas would be far less meaningful (Fig. 10). Julius had recently spared and disbanded the army of Afranius and Petreius, even after Petreius had treacherously murdered his soldiers during a truce. ${ }^{16}$

${ }^{16}$ Caes. $B C 1.75$ and 85 . Also see how Pompey announced that anyone not with him would be treated as an enemy. In response, Julius announced that anyone not against him will be treated like a friend. 

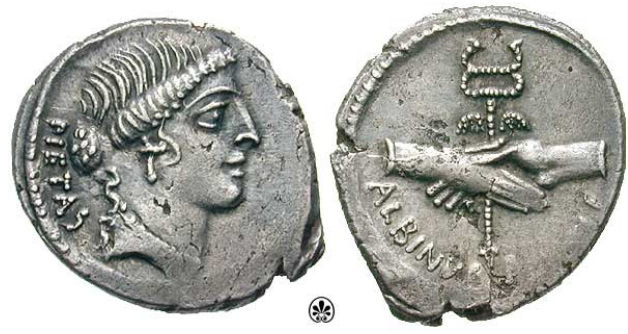

Fig. 10. Dec. Brutus Albinus, denarius, 48 BC. Obv.: PIETAS, clasped hands holding a caduceus
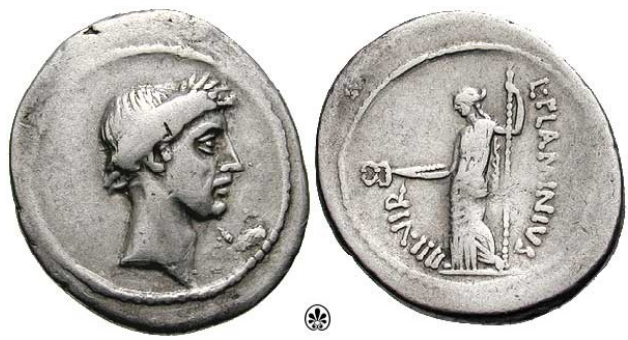

Fig. 12. Flaminius denarius, $43 \mathrm{BC}$. Obv.: wreathed Julius, rev.: Pax, L. FLAMINIUS IIII VIR. $C r$ 485/1
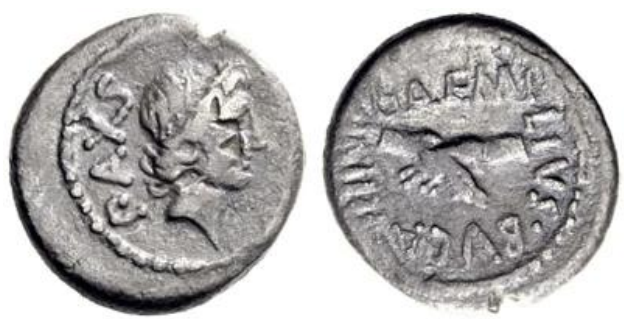

Fig. 11. L. Aemilius Buca, quinarius, 44 BC. Obv.: PAXS head of Pax, rev.: L AEMILIUS BUCA IIIV, clasped hands
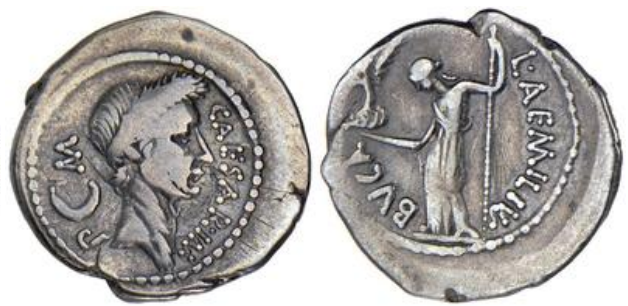

Fig. 13. Buca denarius, 44 BC. Obv.: CAESAR IMP, rev.: L AEMILIUS BUCA, Venus and Victoriola. $\mathrm{Cr} 480 / 4$

The Divine Julius founded in the 40s BC Forum Iulii Pacatum (Fréjus, France) and Pax Iulia (Beja, Portugal), whose names advertise the goddess Pax. ${ }^{17}$ In the final year of his life, a quinarius illustrates the peace and harmony of achieved by Julius' victories with the diademed head of Pax and the legend PAXS on the obverse (Fig. 11). The reverse depicts clasped hands to represent Concordia, much like the coin of Brutus Albinus, but without a caduceus, so that both sides deliver the message that Julius brought the entire empire peace and calm. A greater celebration of Pax was likely anticipated after the victory in the upcoming Parthian War but was rendered moot by the Ides of March.

Nevertheless, in 43, L. Flaminius Chilo minted a denarius often identified as the Divine Julius and Pax with caduceus, ${ }^{18}$ probably for the formation of the Second Triumvirate (Fig. 12). Flaminius Chilo's iconography of Pax unites Cephisodotus's iconography for Eipł́v with earlier Roman coins and also closely resembles the goddess holding a Victory on a denarius of Aemilius Buca from 44 BC (Fig. 13).

\footnotetext{
${ }^{17}$ Honors granted to him by the Senate allowed him to enjoy eternally all of the privileges a triumphator exercised on the day of his triumph (wear a purple toga, receive lictors bearing fasces decked in laurel). Whereas the triumphator, by vanquishing the enemy, has achieved peace and enjoyed great rewards for one day, Julius was to enjoy those privileges permanently, as if he had brought peace to the world.

${ }^{18}$ Ernest Babelon said Juno, most others say Venus. Cf. BABELON, E.: Monnaies de la Republique Romaine II. Paris 1885, Julia 26 Flaminia 3.
} 
Arnoldo Momigliano and W. K. Pritchett concluded that war occurred so frequently as to affect every aspect of Greek life. ${ }^{19}$ This went triple for the Romans. Aside from a single closure of the Gates of Janus between 650 and 30 BC, Rome perpetually waged war. ${ }^{20}$ How did constant warfare affect their impression of peace? ${ }^{21}$ Whereas in the Greek world, peace presented two not irreconcilable concepts, the idyllic and fertile prosperity of Hesiod and Homer or the much needed relief from war, as in Aristophanes and intermittently Homer, for the Romans, Roman Pax was successful imperialism. The very noun pax derives from the verb paciscor "to end a war by

${ }^{19}$ Momigliano, A.: Some Observations on Causes of War in Ancient Historiography. Acta Congressus Madvigiani: Proceedings of the Second International Congress of Classical Studies, 1954 I. Copenhagen 1958, 199-211; reprinted in his Second contributo (Rome 1960) 21 ff., and Studies in Historiography (London 1966), ch. 7: "War was an ever present reality in Greek life; it was a focus for emotions, ethical values, social rules ... War was the centre of Greek life. Yet the amount of attention that Greek political thinkers gave to causes of war is negligible in comparison to the attention they paid to constitutional changes... . The reason, I suspect, is that the Greeks came to accept war as a natural fact like birth and death about which nothing could be done." This is the thesis of PRITCHETT, W. K.: Ancient Greek Military Practice. Berkeley 1971; The Greek City State at War Vol. II-VII. Berkeley 1974, etc. See also ConNor, W. R.: Early Greek Land Warfare as Symbolic Expression. Past \& Present 119 (1988) 3-29, who quotes Momigliano.

${ }^{20}$ Livy 7. 1-2 mentions an episode when there was no warfare in 366-365, but the peace was a mean, hungry time. Again, Liv. 8. 15. 1 says briefly in 338 there was a spell of peace, interrupted by war with the Sidicini: cum omnia non opes magis Romanae quam beneficiis parta gratia bona pace obtineret. Also at Liv. 8. 37.2 a brief peace in 325 was violated by renewed Samnite hostilities: Samnites infecta pace quia de condicionibus agebatur indutias annuas ab urbe rettulerunt; nec earum ipsarum sancta fides fuit; adeo, postquam Papirium abisse magistratu nuntiatum est, arrecti ad bellandum animi sunt. The Byz-

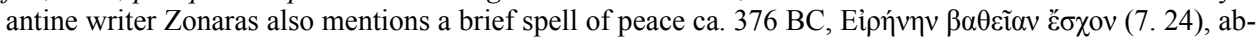
sent from Livy. Otherwise, between 650 and 300, Romans were continuously at war with their neighbors in a never-ending contest to become the dominant power in Italy.

${ }^{21}$ We barely need ask why Rome was always at war. Ancient Italy was a very dangerous place, crowded with aggressive, contending, rival powers. Any sign of weakness encouraged Rome's neighbors to attack. If Rome was the most aggressive, this was only because that was the only way to survive. And the greatest danger in the Roman imagination was the threat of invasion from the North from the Gauls (some civilians cut off their thumbs to avoid fighting in Germany in the aftermath of Teutoburger Wald in AD 9, Suet. Aug. 24. 2; Dio 56. 23. 1). The Republican aristocracy maintained a very high level of military preparedness, while in Greece aggression was partially diverted into athletics. For Roman aristocrats, war was the pursuit that brought wealth and glory, far beyond farming or civic donations or trade before 200 BC. Marxist scholars who claim that the Roman economy was fueled by the expansion of the Roman Empire need to "follow the money", as Mark Felt (Deep Throat) said during Watergate. Although Rome was very successful in war, the officers of victorious commander were disproportionately enriched by plunder, compared to the rest of the population. Aside from occasional boons of largesse, such as after the Third Macedonian War, the average Roman benefited only marginally or not at all from ancient trickledown economics, just as with the Coolidge and Reagan Administrations (1924-1928, 1981-1982). Therefore, at times the common people had to be persuaded that war was beneficial, and peace was not. When Rome was fighting for her survival against Carthage, the aristocrats did not need to stretch the facts to make their case. The incredible century of expansion chronicled by Polybius also made the case well, with a number of incidents in which average Romans genuinely benefited from war. However, the Spanish wars and the last century of the Republic with intermittent civil strife were a much harder sell. It is in this era, particularly in 121 with the construction of the Temple of Concord, that domestic peace has to be asserted as a different entity than international peace. See RAAFLAUB, K.: The Politics of Peace Cults in Greece and Rome. In KÄMMERER, T. R. - KöIV, M.: Cultures in Comparison: Religion and Politics in Ancient Mediterranean Regions. Münster 2015, 103-129. 
the submission of the enemy".22 Some aristocrats were so conditioned to waging war that they saw peace as an impediment to their goals, such as Tullus Hostilius and Sulpicius Galba (cos. 211, 200). When the comitia centuriata refused to declare war in 200 BC against Philip V of Macedon, much to Galba's frustration (Liv. 31. 3-8), he persuaded them that war was inevitable and better fought in Greece than Italy. Most of the time, the militant aristocracy could persuade the people that peace was at best a time of limited or reduced economic growth without the influx of slaves, plunder, jobs, and a demand for military supplies. For a nation that always wins, war can be very profitable - until the expense of maintaining a distant war outweighs the proceeds, which led to the mutinies of the armies of Alexander and Lucullus - while peace can constitute an economic slump. Tyrannical regimes still use war to divert attention from economic misery at home, as recently as Argentina in the Falklands War. Several Roman commanders attacked neighboring peoples with whom Rome was at peace, especially in Spain, for wealth and glory, including Galba's grandson; some were even prosecuted and convicted for it. They viewed peace with the same contempt as Shakespeare's Richard III:

Now is the winter of our discontent

Made glorious summer by this son of York,

(For son of York read son of Romulus)

And all the clouds that lowered upon our house

In the deep bosom of the ocean buried.

Now are our brows bound with victorious wreaths,

Our bruisèd arms hung up for monuments,

Our stern alarums changed to merry meetings,

Our dreadful marches to delightful measures.

Grim-visaged war hath smoothed his wrinkled front;

And now, instead of mounting barbèd steeds

To fright the souls of fearful adversaries,

He capers nimbly in a lady's chamber

To the lascivious pleasing of a lute.

...

Why, I, in this weak piping time of peace,

Have no delight to pass away the time,

Unless to see my shadow in the sun

And descant on mine own deformity. ${ }^{23}$

\footnotetext{
${ }^{22}$ See WeinStock, S.: Pax and the Ara Pacis. JRS 50 (1960) 44-58, n. 12.

${ }^{23}$ Richard III I 1. 1-13 ff. By total coincidence, the grandfather of the emperor Galba had a hunchback, Suet. Galba 3; Macr. 2. 4. 8, 2. 6. 3-4, like the caricature of Richard III.
} 

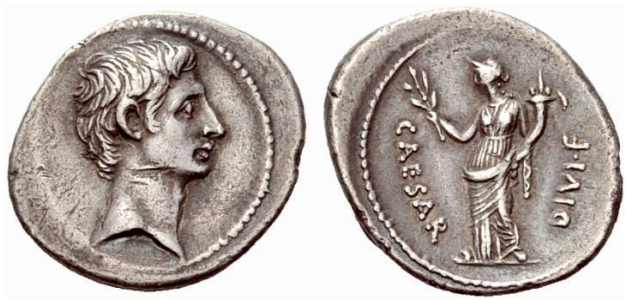

Fig. 14. Caesarian denarius? Brundisi mint 31 BC. Obv.: bare head of Caesar, rev.: CAESAR DIVI F, Pax holding olive branch, cornucopia. RIC 252, CBD 26, AMC 194, $B M C R E$ 605, Babelon 115
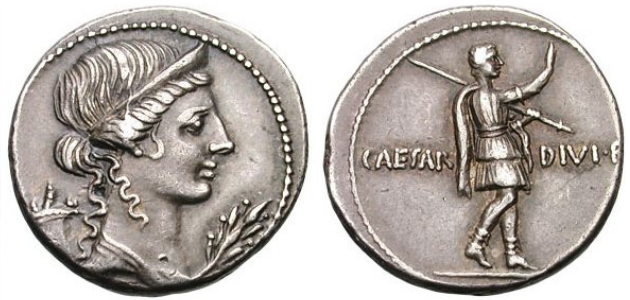

Fig. 15. Caesarian denarius, $31 \mathrm{BC}$.

Obv.: Pax wears a stephane, olive branch in front, Cornucopia behind,

rev.: CAESAR DIVI F Caesar saluting, holding spear or staff. RIC 253

\section{AUGUSTUS}

Even after decades of on-again, off-again civil war, Augustus faced a challenge in persuading his fellow countrymen that peace could work and be beneficial. The mood of the times helped ease his task. In the recent past the people, weary of the gut wrenching civil wars, twice had begged to avoid another war: in 40 the soldiers insisted he come to terms with Antony in the Pact of Brundisium, which resulted in the marriage of the recently widowed Octavia to Antony to form a bond between them. ${ }^{24}$ And again in 39, the people compelled him to settle with Sextus Pompey at the Pact of Tarentum, much against his will. ${ }^{25}$ But peace did not long endure. Sextus was defeated and driven east in 36 to his death (in 35). War with Antony followed in 32.

On the eve of Actium, ${ }^{26}$ Caesar released a pair of denarii depicting Pax, recognizable by the olive branch and cornucopia, but without the caduceus, which apparently was not a required attribute (Figs. 14-15). These denarii reassert yet again his association with the Divine Julius by recalling the Paxs coinage of 44, presenting the Young Caesar as the true head of the Caesarian faction. Furthermore they assert his legitimacy as the leader of the Romans who want peace, or can bring peace through victory (the normal way to win Roman peace) ${ }^{27}$ So he, rather than the corrupted Antony, will defend and/or restore Pax to the world. As events turned out, after Actium Caesar had the chance to prove it, for which he received the name Augustus "Holy One". The unconventional genius of Augustus was his ability to impress upon the Roman people a new sort of peace that did not rely solely upon military victory, but also on somewhat idealistic themes from Greek and Roman literature and religion (Greek ideals, despite his back to mos maiorum public campaign against Antony) and the benefits of peace, compared to the madness of civil war as the alternative. Although this

\footnotetext{
${ }^{24}$ Vell. 2. 76. 3; Liv. Per. 127. 51-53; Plut. Ant. 30; App. BC 5. 7. 64; Dio 48. 54.4.

${ }^{25}$ App. $B C$ 5. 8. 68. Cf. Dio 48. 31. 5-6, who tells a slightly different story.

${ }^{26}$ SEAR, D.: The History and Coinage of the Roman Imperators 49-27 BC. London 1998, 242-244.

${ }^{27}$ MOMigliano (n. 1).
} 
may sound like a simple choice, one must remember that his rivals and predecessors for the previous generations had not succeeded or in most cases even tried to instill peace.

It took Augustus's friends a year to devise how to present peace to the Roman people as a benefit. Their efforts met with an outpouring of joy and certainly relief, according to Vell. 2. 89. 3-4, after for 20 years of civil war that had plagued Rome.

Finita vicesimo anno bella civilia, sepulta externa, revocata pax, sopitus ubique armorum furor, restituta vis legibus, iudiciis auctoritas, senatui maiestas, imperium magistratuum ad pristinum redactum modum, tantummodo octo praetoribus adlecti duo. Prisca illa et antiqua rei publicae forma revocata. Jediit cultus agris, sacris honos, securitas hominibus, certa cuique rerum suarum possessio; leges emendatae utiliter, latae salubriter; senatus sine asperitate nec sine severitate lectus. Principes viri triumphisque et amplissimis honoribus functi adhortatu principis ad ornandam urbem inlecti sunt.

In the twentieth year, the last civil war came to an end, and since foreign conflict was buried, peace was declared. In all places the madness for arms was lulled to sleep. Power was returned to the laws, authority to judgments, dignity to the Senate, the authority of the magistrates returned to its ancient power, save only that to the eight praetors two more were added. The pristine and ancient form of the Republic was brought back. Agriculture returned to the fields, honor returned to the sacred rites, safety to mankind, to each individual the right to possess his own property unmolested. Laws were emended for the better, new ones made for the common weal; membership in the Senate was revised with neither bitterness nor harshness. The leading men of state enjoyed triumphs and multiple honors, and at the urging of the First Senator (Augustus), they were persuaded to adorn the city. (transl. G. Stern)

Most important of all, peace was declared, and the Gates of Janus were shut. ${ }^{28}$ For the first time in almost 200 years, Rome was officially at peace. A tetradrachma from the Ephesus mint proclaims the incredible state of peace, on which Pax holds a caduceus in her right hand beside the mystical cistera from which a snake (? or plant) emerges (Fig. 16). Augustus' corona civica encircles the field of the reverse to ensure that all properly assign credit to him for creating from a state of civil war the Pax Augusta (Gibbon calls it the Pax Romana) through the right mix of Romulus and Numa.

The regime argued that Peace is actually good for Romans because it let fathers watch their children grow up, and it led to a fraternal feeling not just within families recently torn apart by civil war, but also across society. According to the faction in power, Peace would increase prosperity, contrary to the traditional view, that only war could bring loot and prosperity, so long perpetuated with trickle-down economics.

${ }^{28}$ Res. Gest. 13; Vell. 2. 38. 3; Liv. 1. 19. 3; Flor. 2. 34. 64; Suet. Aug. 22; Dio 51. 20. 4; Oros. 6. 20. 8, 6. 22. 1. Dio also says the Senate granted him the power to enroll new priests, the power to enroll new patricians, and an annual celebration on the dates of his great victories. 

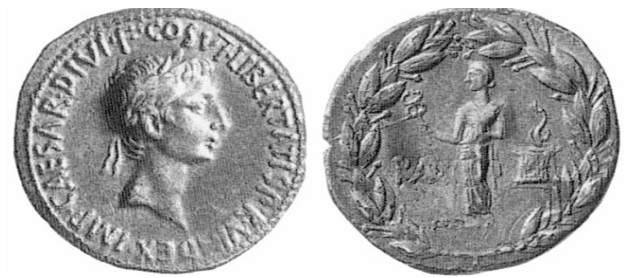

Fig. 16. Ephesus tetradrachma.

Obv.: IMP CAESAR DIVI F COS VI LIBERTATIS PR VINDEX, Augustus, rev.: Pax, cisterna. RIC 476

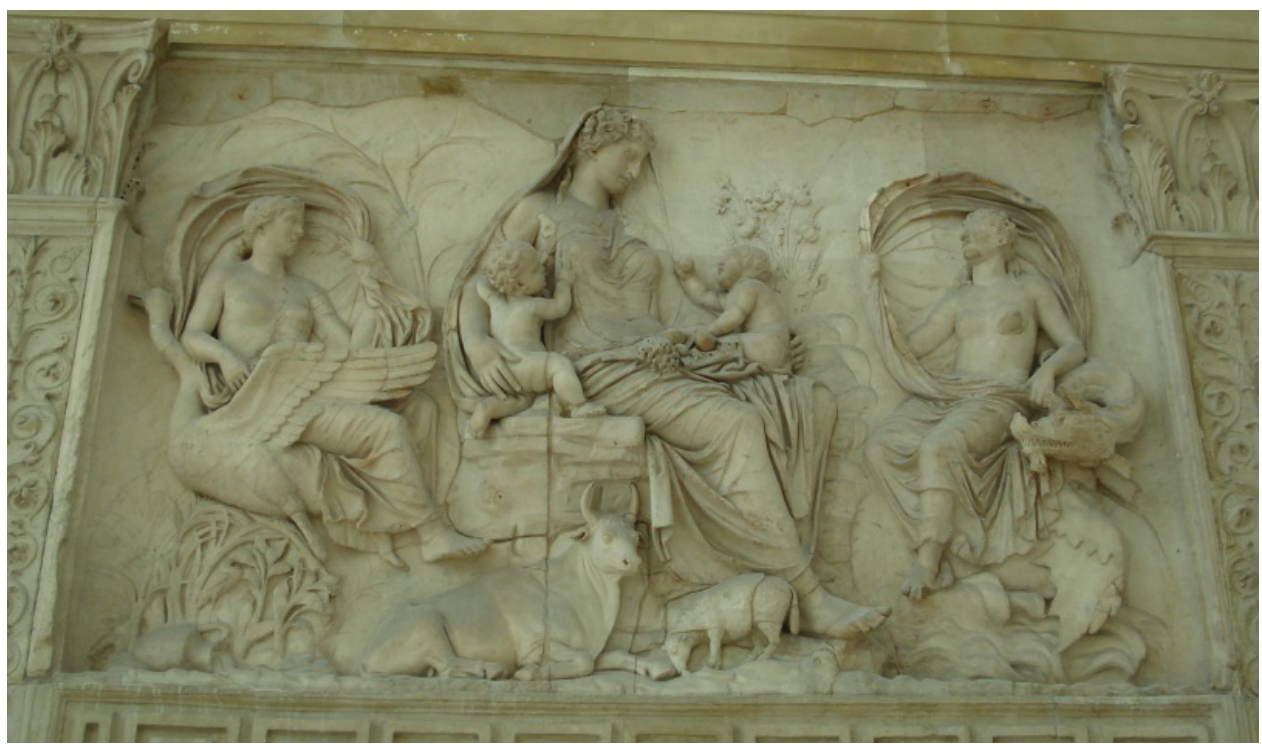

Fig. 17. Pax Augusta on the Ara Pacis Augustae (Photo Gaius Stern)

Additionally, it reasoned that Peace promotes justice, a winning argument in the provinces, which in the late Republic had too often suffered from rapacious governors.

Augustus skillfully integrated certain Greek concepts of peace into the Roman vocabulary, where they did not already exist. Her iconography and qualities derive partly

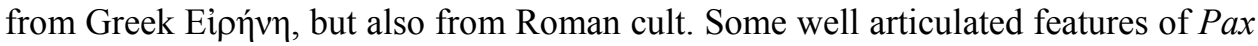
Augusta were prosperity and fertility, both of which vividly appear as attributes on the Ara Pacis (Fig. 17). The wheat and fruits denote the return to agriculture (as many veterans were settled on farmland) and agricultural fertility in peacetime. The twins on her lap are not specific individuals (or we no longer know their identities), rather they represent domestic harmony achieved in the absence of (civil) war. In essence, they are human fertility when a father is at home (rather than away at war), allowing prosperity. ${ }^{29}$

The cow and sheep not only represent a flux in animal husbandry, they are two of the three correct animals for a sacrifice to Pax (along with the pig on the front),

${ }^{29}$ ZANKER, P.: The Power of Images in the Age of Augustus. Ann Arbor 1990, 119. 
enacted at this very altar. Roman state art often shows afterwards the very event that took place on this very spot in an interrelation between art and history, such as the Arch of Titus showing his triumph on the very spot where his chariot entered the Roman Forum (this is the Gaius Stern "Washington Slept Here theory" of Roman state art).

This new cult figure, Pax Augusta, continued to evolve long after Augustus. A Vespasianic denarius retains some features of the Paxs denarius from 44, with the head of the crowned goddess looking right, but most coins show the entire body of the goddess. Pax Augusta may be seated, stand, walk, run, and even stand burning the enemy's weapons (a throwback to the older traditional Pax). She only rarely holds the caduceus through the time of Aurelian (r. AD 270-275) on coinage (Figs 18A-F).

While the goddess on the Ara Pacis panel has characteristics common to (and borrowed from) other cult figures, the imagery fits well with the claims of success Augustus makes in Res Gestae. Furthermore, from Augustus' boast in Res Gestae 13, "I closed the Gates of Janus three times", one can be sure that the ruling coalition of Caesarians succeeded in their goal of validating peace to the people, for the boast would not be praiseworthy - perhaps even embarrassing - if war were still the only proper modus operandi and peace an inconvenience. Furthermore, we have Ovid's testimony in Fast. 1. 709 ff., 3.879 ff. that Pax had annual feast days (30 January, 30 March) as additional proof of their success.

\section{DOMESTIC AND INTERNATIONAL PEACE ON THE NORTH AND SOUTH FRIEZES}

Every wall of the Ara Pacis contains imagery of peace. On the North and South Friezes, the dignitaries wearing the toga - the garment of peace - emphasize the solemn, religious message in a variety of complex and interrelating images that illustrate the new Pax Augusta the world was to enjoy, had all gone according to plan (the death of Agrippa was the chief impediment in the eyes of the regime to explain why the intended peace never fully bloomed). The Ara Pacis displayed peace as the fruition of years of effort of the united nobility, led by the principes, which is why so many figures crowd the long friezes in addition to Augustus and Agrippa. If this were a dynastic monument instead of a celebration of the common cause of the nobility, we would see only Augustus, Agrippa, and a few relations, probably all of whom would have some Julian connection. The very number of participants proves it is not a dynastic monument and that it celebrates a great number of senators whose loyalty is rewarded (or entreated) by their inclusion. One must remember the nobility wished to be included on the Ara Pacis as proof that they had made a contribution and their efforts were recognized. This point is important because many scholars write as if the Ara Pacis was built by and for Augustus alone. Again, since it was the Senate that built this monument to honor the Roman achievement, leading senators made sure they appeared on the friezes in a recognizable form. ${ }^{30}$ tify them.

${ }^{30}$ Today's foreground heads on the North Frieze are not authentic so it is fruitless to try to iden- 


\section{FIGS 18A-F. PAX AUGUSTA COINS FROM VESPASIAN TO AURELIAN}
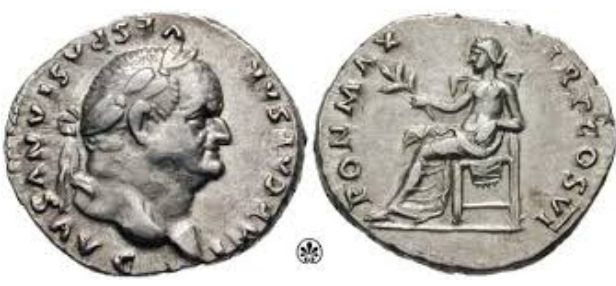

A. Vespasian denarius, Roman mint ca. 72 AD, obv.: IMP CAESAR VESPASIANVS AVG, rev.: PON MAX TRP COS VI, Pax seated left holding branch (olive or laurel). RIC II 770
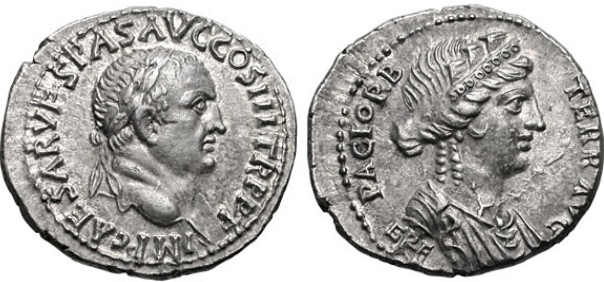

B. Vespasian denarius, Ephesus mint, 71 AD. Obv.: IMP CAESAR VESPAS AVG COS III TR P P P, rev.: PACI ORB TERR AVG, towered et draped bust of World Peace right, EFE in ex. RIC 1433 (collection Gaius Stern)
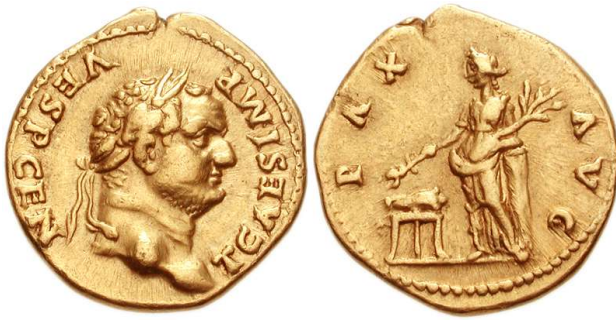

C. Titus as Caesar, aureus. 73 AD. Obv.: T CAES IMP VESP CEN, rev.: PAX AVG, pax standing left, leaning on column to right, holding winged caduceus over tripod and olive-branch. RIC 551 Vesp.

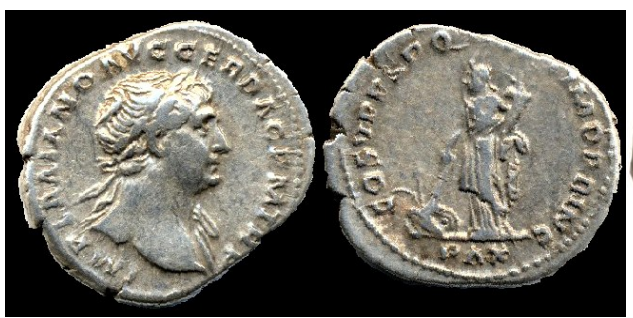

E. Trajan denarius ca. 105 AD. Obv.: IMP TRAIANO AVG GER DAC P M TR P, rev.: COS. V. P.P. S.P.Q.R. OPTIMO

PRINC, PAX in ex. Pax holding cornucopia, setting fire to pile of arms
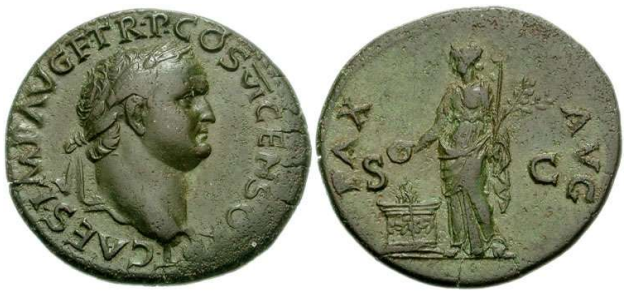

D. Titus, dupondius, Lyons mint. ca. 75 AD.

Obv.: T CAES IMP AVG F TR P COS VI CENSOR, laureate head right, rev.: PAX AVG S-C,

Pax holding patera over altar, caduceus \& olive. RIC 1261
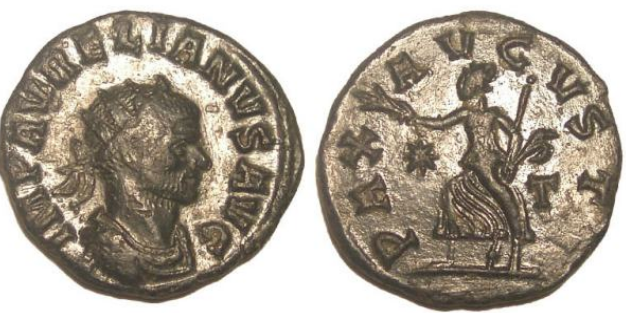

F. Aurelian, antoninianus, Siscia mint. Obv.: IMP AVRELIANVS AVG, rev.: PAX AVGVSTI, Pax advancing left, holding branch and scepter; star on field (collection Gaius Stern) 


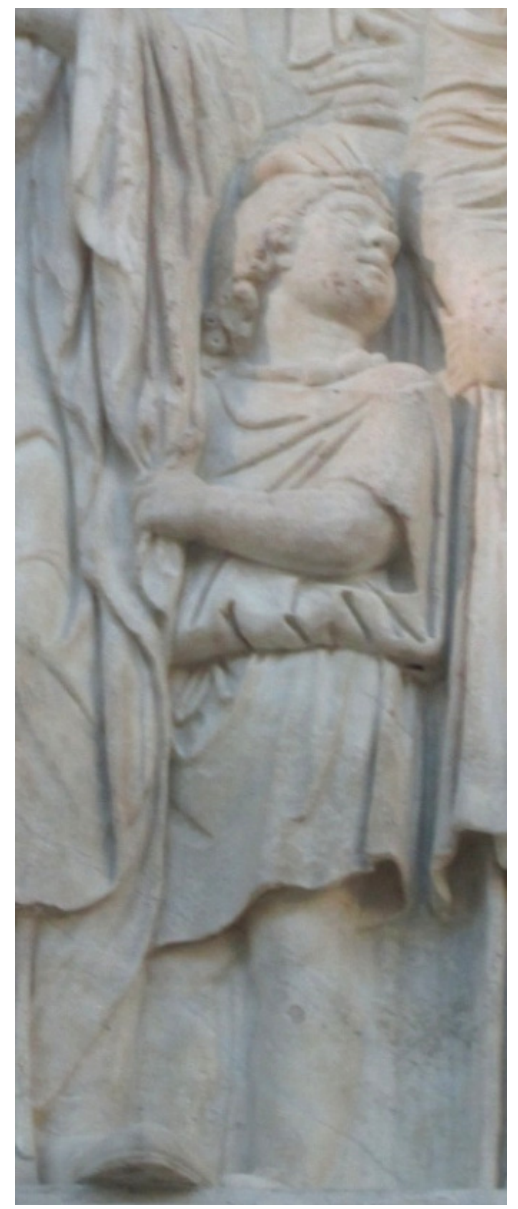

Fig. 19. Eastern Prince (Photo Gaius Stern)

A few former enemies who had backed Sextus Pompey and Antony before recognizing Augustus' auctoritas can be discerned among the membership of the priestly colleges on the North Frieze, physical proof for the contemporary audience that conflict between them has been buried in favor of peace and concord.

In addition to the domestic peace between former enemies in the civil war, the Ara Pacis also boldly displays international peace due to a strong defense of the borders (we call this the conquest) and diplomacy. All three continents of the world are represented as respecting Roman authority and wisdom. On the South Frieze, a guest from the Parthian Empire, currently fostered by Agrippa and Julia participates in the procession, hanging onto Agrippa's toga (Fig. 19). If he is in fact a hostage, he is not publicly described as such, but more as a foreign prince in Rome to learn Roman ways. After imperial propaganda on coinage in $19 \mathrm{BC}$ had crossed the line and belittled the Parthians, voiding the brief opportunity for détente when the Parthians returned the 
Roman standards, it seems likely that efforts were made to halt additional indiscreet statements. Thus the Parthian prince simultaneously shows that Rome and Parthia are at peace after the troubles with Crassus and Antony, and that the Parthians respect Roman ways by sending their royalty for an education to Rome. Rome is the new School of the World, as Pericles had once boasted of Athens. ${ }^{31}$

Gaius Stern

University of California, Berkeley

History of Art (Rome, Greece)

431 Doe Library

Berkeley, CA 94720

${ }^{31}$ See Thuc. 2. 41. 1. Now Rome held Athens" former role of "the school of Greece" on a larger stage. 